\title{
Effect of high water temperature on natural resistance of cultured Oreochromis niloticus
}

\author{
M. N. M. Ali * \\ Department of Fish Diseases, Animal Health Research Institute, Dokki, Giza, Egypt
}

\begin{abstract}
Killing activity of fresh Oreochromis niloticus serum was used as an indicator of the natural immunity. Serum killing activity was tested in temperature stressed fish exposed to $32 \pm 1^{\circ} \mathrm{C}$ to different Pseudomonas fluorescens strains. As a clinical estimate of natural immunity and disease resistance, experimental challenge with $P$. fluorescens strains was conducted. The results cleared that serum killing activity at $32 \pm 1^{\circ} \mathrm{C}$ was almost stopped where fish got infected after bacterial challenge. On the other hand, control fish group kept at $23 \pm 1^{\circ} \mathrm{C}$ developed serum killing activity and resistance to the acquisition of infection after challenge. A correlation was found between resistance activities of $P$. fluorescens strains to serum killing and their corresponding courses of infection after bacterial challenge. However, the results of experimental challenge conducted at $32 \pm 1^{\circ} \mathrm{C}$ suggested that the immunocompromising state resulted from the stress of inability to withstand high water temperature is exclusively the critical aspect for the induction of infection.
\end{abstract}

Fish culture activities in different regions have different upper and lower thermal tolerance limits as well as optimum water temperatures for various physiological activities e.g. growth, food conversion, egg incubation and disease resistance. Like all other ectoth-ermic vertebrates, the immune response of fish is also temperature dependent where extremes of high or low water temperature may delay or even completely abolish this response rendering fish more susceptible to opportunistic pathogens as $P$. fluorescens (Austin and Austin, 1989 ).

P. fluorescens infection in fish is usually associated with haemorrhagic septicaemia. The condition is usually predisposed by environmental stress, especially high water temperatures (Roberts, 2001). The pathogennesis of $P$. fluorescens in fish is multifactorial, where various factors related to the fish, environment and the pathogen itself work together to express the disease condition (Post, 1987 ) .

Development of non-specific immunity in fish to some common pathogens and the existence of serum resistance activities among them were studied (Mittal et. al., 1980; Janada et. al., 1984). Such criteria may also help $P$. fluorescens to resist attack by the natural immunity of the fish.

Thus, the present work was planned to characterize the relationship between high water temperature and the natural immunity of $O$. niloticus by the estimation of fish serum killing activity to different $P$. fluorescens strains. Besides, experimental challenge was used to prove such relationship.

\section{Materials and Methods}

Naturally infected fish. Naturally infected Oreochromis niloticus showing signs of septicaemia were collected from some commercial fish farms in Egypt. Fish were subjected to clinical and postmortem examinations as described (Austin and Austin, 1999; Noga, 2000).

Fish for experimental study. 200 apparently healthy individuals of $O$. niloticus weighing approximately $70 \pm 5 \mathrm{~g}$ were collected from a commercial fish farm and maintained in well-aerated water in fully prepared glass aquaria at $23 \pm 1{ }^{\circ} \mathrm{C}$. All fish were fed comercial pellets at $1 \%$ body weight daily. 
Recovery of $\boldsymbol{P}$. fluorescens. Isolation and identification of $P$. fluorescens from apparently healthy and diseased fish were carried out according to the methods described by Lennette et. al., (1985) and Balows et al., (1992) using Tryptic Soy Agar (TSA, Difco) for primary isolation.

Assay of serum killing activity to $P$. fluorescens. This assay was carried out on the basis of Yancey et. al. (1979). Serum was separated from blood samples of $P$. fluorescens experimentally infected fish groups. $P$. fluorescens was grown in tryptic soy broth (TSB) at $25 \pm 1{ }^{\circ} \mathrm{C}$ for $24 \mathrm{~h}$ were collected by centrifugation and washed with PBS. The cell suspension with a bacterial count of $2 \times 10^{6}$ $\mathrm{CFU} / \mathrm{ml}$. mixed with serum to give a final serum concentration of $50 \%$. The mixtures were incubated at $25 \pm 1^{\circ} \mathrm{C}$ for $3 \mathrm{hr}$ where $0.1 \mathrm{ml}$ samples were taken for monitoring bacterial survival ability by viable plate count on TSA. A ratio was calculated to represent the survivability of $P$. fluorescens in O. niloticus sera.

Experimental design. Ten fish groups (20/group) each were used for experimental study. Two fish groups were used for each P. fluorescens strain where the first group was kept at $23 \pm 1^{\circ} \mathrm{C}$, while fish in the second group were thermally stressed gradually by adjusting aquarium temperature to $32 \pm 1^{\circ} \mathrm{C}$ using thermostatically adjusted heaters. All fish groups were monitored by continuous examination for behavioral changes and mortalities for 2 days during which pooled blood samples (5 samples) were collected for serum separation at 4,12 , 30 and $48 \mathrm{~h}$ post infection. Serum samples were run in the assay of serum killing activity as described above using the recovered $P$. fluorescens strains. As a control, heat-inactivated serum at $56{ }^{\circ} \mathrm{C}$ for 30 minutes (Sakai, 1981) was used. All fish groups were then challenged by removing fish from their aquaria and immersing in 2-L cell suspension of corresponding $P$. fluorescens $\left(2 \times 10^{6} \mathrm{CFU} / \mathrm{ml}^{-}\right.$

$\left.{ }^{1}\right)$ for 5 minutes and then returning fish to their home aquaria. Fish groups were examined for the development of clinical signs, lesions, mortalities and bacterial reisolation throughhout 7 days .

\section{Results and Discussion}

Pseudomonas fluorescens was successfully recovered from internal organs of both apparently healthy and diseased $O$. niloticus showing signs of septicaemia. Clinically, infected fish demonstrated haemorrhagic skin and fin lesions, abdominal dropsy, exophthalmia and fin rot (Fig.1). Internally, there were visceral congestion and haemorhages, ascites and adhesion of internal organs. The severity of these signs and lesions varied among examined infected fish and revealed the existence of acute septicaemic and chronic courses of $P$. fluorescens infection supporting the results recorded by Peterinec et al (1985), Abdel-Aziz (1988), Noga (2000) and Roberts (2001).

Bacteriological examination of healthy and diseased fish resulted in the identification of five P. fluorescens strains designated S-1, to S-5 with the last one being isolated from apparently healthy fish. The recovery of S-5 from apparently healthy fish may reflect the existence of latent or subclinical form of infection, supporting the results of Ahne et al. (1982) who found that additional environmental stressor is required for the exaggeration of latent $P$. fluorescens infection in Tench fry .

Regarding serum killing activity at $23 \pm 1^{\circ} \mathrm{C}$, Table (1) showed that survival and resistance abilities of $P$. fluorescens strains expressed as CFU counts and its corresponding serum resistance activities values were progressively decreased throughout all time points for all strains, which in other mean indicate the existence of acceptable levels of serum killing activities at such immuonocompetent water temperature. However, S-1 and S-4 were highly resistant to serum killing at $23 \pm 1{ }^{\circ} \mathrm{C}$ than other strains. Meanwhile S-5 developed serum hypersensitivity at $23 \pm 1^{\circ} \mathrm{C}$. On the other hand, at $32 \pm 1^{\circ} \mathrm{C}$ (Table 2), serum killing activity was almost stopped for all strains, however, S-1 and S-4 did not only survive in the fresh serum but also grew in it. These results proved the immunosuppressive status occurred at high water temperature $\left(32 \pm 1^{\circ} \mathrm{C}\right)$ and its drastic effects on natural serum killing activities which is reflected by an increased CFU and their corresponding resistance activities. The recorded differences in the values of serum survival and resistance abilities of $P$. fluorescens strains may reflect 


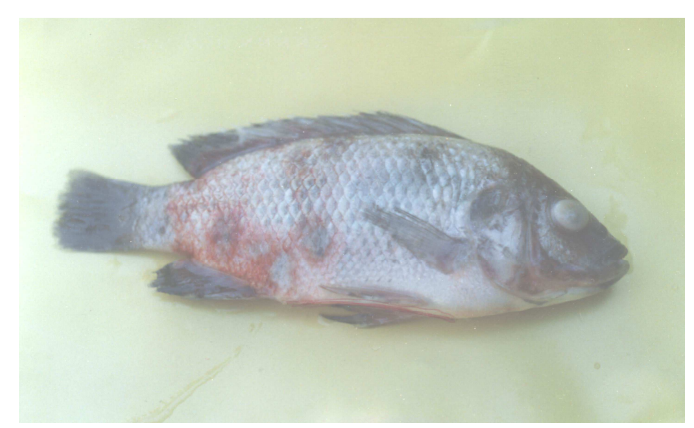

Fig.1 Naturally infected $O$. niloticus showing haemorrhagic skin with fin and tail rot.

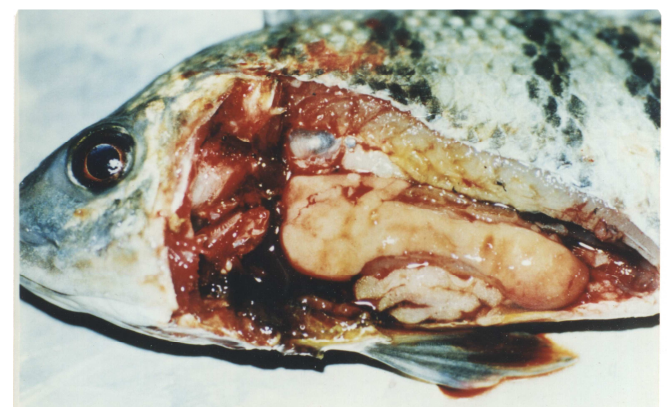

Fig. 2 Experimentally infected $\boldsymbol{O}$. niloticus showing congestion of internal organs with enlarged degenerated liver.

the variations in the actual virulence profile mediated by these strains against serum killing. Meanwhile, killing activity by heat-inactivated serum was almost eliminated (Table 1,2) for all strains at both temperatures. Since serum killing activity was heat-labile, it could be linked with complement (Yancey et al.,1979; Sakai,1981).

Fish groups subjected to experimental challenge with different $P$. fluorescens strains at $23 \pm 1{ }^{\circ} \mathrm{C}$ developed no signs or lesions or any other symptomatic changes indicating disease condition and confirming the opportunistic character of $P$. fluorescens (Roberts, 2001). On the other hand, fish groups stressed at $32 \pm 1{ }^{\circ} \mathrm{C}$ and challenged with the corresponding strains demonstrated variable extents of clinical signs, lesions and mortalities.

S-1 and S-4 induced $100 \%$ mortalities within $24-48 \mathrm{~h}$ post challenge with the development of sluggish movement, loss of balance and reflexes as well as development of abdominal dropsy (Fig. 2), skin and fin haemorrhages. Internally there were visceral haemorrhages and accumulation of ascites fluid abdominally. These results support those of Noga (2000) and Roberts (2001) regarding the ascitic form of $P$. fluorescens infection.
S-2 and S-3 induced 50\% and 70\% mortalities respectively within $96 \mathrm{~h}$ post challenge. Infected fish developed darkening in skin colour, haemorrhagic skin and fin lesions, ascites and fin rot. Internally there were petechiation of visceral organs, accumulation of purulent ascites fluid abdominally as well as visceral adhesions. Visceral adhesion may result from the organization of ascites fluid with subsequent deposition of fibrin, which is characteristically associated with chronic type of $P$. fluorescens infection (Noga, 2000; Roberts, 2001).

S-5 induced $20 \%$ mortalities where infected fish developed skin and fin petechiation especially at fin bases and abdominal region as well as congestion of internal organs. The low mortality percentage and the restricted signs and lesions confirm the results of S-5 serum hypersensitivity and its limited virulence profile. Variations in the recorded clinical signs, lesions, mortalities and bacterial re-isolation among challenged fish groups matched the variations recorded among $P$. fluorescens strains for their serum resistance activities suggesting the existence of different virulence profiles participating in the mechanism of host-pathogen interaction and consequently the overall disease course. Many authors reviewed the characterization of virulence states of bacterial strains and attributed it to the existence of some virulence factors as proteases, haemolysins, enterotoxins, cytotoxins and others (Allan and Stevenson, 1981). However, the virulence profile to the quantity of the produced toxins rather than this qualitative disposition (Kou, 1973; Oliver et al., 1985). The occurrence of variable courses of $P$. fluorescens infections in fish ranging from acute rapidly developing one in some instances to slow developing or even latent in others may agree with the recorded diversity of $P$. fluorescens strains and the existence of environmental as well as miscellaneous biotypes (Krieg and Holt, 1984; Post, 1987 ).

Successful bacterial recovery was only carried out from internal organs of fish groups challenged at $23 \pm 1{ }^{\circ} \mathrm{C}$ with S- 1 and S4 , the highly serum resistance strains suggesting that virulent $P$. fluorescens strains can overcome some of the fish natural 

Table (1): Serum killing activity to $P$. fluorescens strains at $23 \pm 1^{\circ} \mathrm{C}$.

\begin{tabular}{|c|c|c|c|c|c|c|c|c|c|}
\hline \multirow{3}{*}{$\begin{array}{c}\text { Strain } \\
\text { Number }\end{array}$} & \multirow[t]{3}{*}{ Serum Sample } & \multicolumn{8}{|c|}{ Resistance Activity } \\
\hline & & \multicolumn{2}{|c|}{$4 \mathrm{~h}$} & \multicolumn{2}{|c|}{$12 \mathrm{~h}$} & \multicolumn{2}{|c|}{ 30h } & \multicolumn{2}{|c|}{$48 \mathrm{~h}$} \\
\hline & & ${ }^{*} \mathrm{CFU} / \mathrm{ml}$ & ** SKA & ${ }^{*} \mathrm{CFU} / \mathrm{ml}$ & $* *$ SKA & ${ }^{*} \mathrm{CFU} / \mathrm{ml}$ & $* *$ SKA & ${ }^{*} \mathrm{CFU} / \mathrm{ml}$ & ** SKA \\
\hline \multirow{3}{*}{ S-1 } & Fresh & $4.72 \times 10^{5}$ & 0.236 & $2.91 \times 10^{5}$ & 0.1455 & $2.32 \times 10^{5}$ & 0.116 & $2.14 \times 10^{5}$ & 0.107 \\
\hline & Heat-inactivated & $4.11 \times 10^{6}$ & 2.055 & $6.24 \times 10^{6}$ & 3.12 & $8.92 \times 10^{6}$ & 4.46 & $9.72 \times 10^{6}$ & 4.86 \\
\hline & Fresh & $1.22 \times 10^{5}$ & 0.061 & $7.32 \times 10^{4}$ & 0.0366 & $7.10 \times 10^{4}$ & 0.0355 & $6.41 \times 10^{4}$ & 0.0321 \\
\hline \multirow[t]{2}{*}{ S-2 } & Heat- inactivated & $3.14 \times 10^{6}$ & 1.57 & $5.21 \times 10^{6}$ & 2.605 & $7.43 \times 10^{6}$ & 3.715 & $8.30 \times 10^{6}$ & 4.15 \\
\hline & Fresh & $1.80 \times 10^{5}$ & 0.09 & $1.27 \times 10^{5}$ & 0.0635 & $1.08 \times 10^{5}$ & 0.054 & $0.92 \times 10^{5}$ & 0.046 \\
\hline \multirow[t]{2}{*}{ S-3 } & Heat- inactivated & $3.02 \times 10^{6}$ & 1.51 & $5.10 \times 10^{6}$ & 2.55 & $8.21 \times 10^{6}$ & 4.105 & $8.93 \times 10^{6}$ & 4.465 \\
\hline & Fresh & $2.94 \times 10^{5}$ & 0.147 & $1.73 \times 10^{5}$ & 0.0865 & $1.42 \times 10^{5}$ & 0.071 & $1.19 \times 10^{5}$ & 0.0595 \\
\hline \multirow[t]{2}{*}{ S-4 } & Heat- inactivated & $3.90 \times 10^{6}$ & 1.95 & $5.73 \times 10^{6}$ & 2.865 & $7.54 \times 10^{6}$ & 3.77 & $9.46 \times 10^{6}$ & 4.73 \\
\hline & Fresh & $4.12 \times 10^{3}$ & 0.0021 & $2.81 \times 10^{3}$ & 0.0014 & $1.62 \times 10^{3}$ & 0.0008 & $1.46 \times 10^{3}$ & 0.0007 \\
\hline S-5 & Heat- inactivated & $2.50 \times 10^{6}$ & 1.25 & $3.26 \times 10^{6}$ & 1.63 & $5.01 \times 10^{6}$ & 2.505 & $5.60 \times 10^{6}$ & 2.8 \\
\hline
\end{tabular}

$* \mathrm{CFU}=$ Colony forming unit

** SKA $=$ Serum Killing Activity - Values greater than 1 indicate full bacterial resistance

Table (2): Serum killing activity to $P$. fluorescens strains at $32 \pm 1^{\circ} \mathrm{C}$.

\begin{tabular}{|c|c|c|c|c|c|c|c|c|c|}
\hline \multirow{3}{*}{$\begin{array}{c}\text { Strain } \\
\text { Number }\end{array}$} & \multirow{3}{*}{ Serum Sample } & \multicolumn{8}{|c|}{ Resistance Activity } \\
\hline & & \multicolumn{2}{|c|}{$4 \mathrm{~h}$} & \multicolumn{2}{|c|}{$12 \mathrm{~h}$} & \multicolumn{2}{|l|}{ 30h } & \multicolumn{2}{|c|}{$48 \mathrm{~h}$} \\
\hline & & $* \mathrm{CFU} / \mathrm{ml}$ & $* *$ SKA & ${ }^{*} \mathrm{CFU} / \mathrm{ml}$ & ** SKA & $* \mathrm{CFU} / \mathrm{ml}$ & $* *$ SKA & $* \mathrm{CFU} / \mathrm{ml}$ & ** SKA \\
\hline \multirow{3}{*}{ S-1 } & Fresh & $2.41 \times 10^{6}$ & 1.205 & $3.12 \times 10^{6}$ & 1.56 & $4.13 \times 10^{6}$ & 2.065 & $4.22 \times 10^{6}$ & 2.11 \\
\hline & Heat-inactivated & $3.92 \times 10^{6}$ & 1.96 & $6.14 \times 10^{6}$ & 3.07 & $8.69 \times 10^{6}$ & 4.345 & $9.30 \times 10^{6}$ & 4.65 \\
\hline & Fresh & $2.54 \times 10^{5}$ & 0.127 & $2.82 \times 10^{5}$ & 0.141 & $3.44 \times 10^{5}$ & 0.172 & $3.60 \times 10^{5}$ & 0.18 \\
\hline \multirow[t]{2}{*}{ S-2 } & Heat-inactivated & $3.21 \times 10^{6}$ & 1.606 & $5.54 \times 10^{6}$ & 2.77 & $7.52 \times 10^{6}$ & 3.76 & $8.26 \times 10^{6}$ & 4.13 \\
\hline & Fresh & $2.63 \times 10^{6}$ & 0.1315 & $2.92 \times 10^{5}$ & 0.146 & $3.81 \times 10^{5}$ & 0.1905 & $3.96 \times 10^{5}$ & 0.198 \\
\hline \multirow{2}{*}{ S-3 } & Heat-inactivated & $2.83 \times 10^{6}$ & 1.415 & $4.25 \times 10^{6}$ & 2.125 & $7.91 \times 10^{6}$ & 3.955 & $8.32 \times 10^{6}$ & 4.16 \\
\hline & Fresh & $2.65 \times 10^{6}$ & 1.325 & $3.28 \times 10^{6}$ & 1.64 & $3.86 \times 10^{6}$ & 1.93 & $3.79 \times 10^{6}$ & 1.895 \\
\hline \multirow[t]{2}{*}{ S-4 } & Heat-inactivated & $3.42 \times 10^{6}$ & 1.71 & $5.86 \times 10^{6}$ & 2.93 & $7.94 \times 10^{6}$ & 3.97 & $9.12 \times 10^{6}$ & 4.56 \\
\hline & Fresh & $7.22 \times 10^{4}$ & 0.0361 & $7.34 \times 10^{4}$ & 0.0367 & $7.51 \times 10^{4}$ & 0.0375 & $7.48 \times 10^{4}$ & 0.0374 \\
\hline S-5 & Heat-inactivated & $2.63 \times 10^{6}$ & 1.315 & $3.32 \times 10^{6}$ & 1.66 & $4.82 \times 10^{6}$ & 2.41 & $5.33 \times 10^{6}$ & 2.665 \\
\hline
\end{tabular}

$* \mathrm{CFU}=$ Colony forming unit

** SKA $=$ Serum Killing Activity - Values greater than 1 indicate full bacterial resistance 
barriers to invade internal organs even at optimum environmental temperature $\left(23 \pm 1^{\circ} \mathrm{C}\right)$ resulting in a case of sub-clinical or latent form of infection as recorded by the absence of clinical signs. Such results may indicate that at optimum environmental temperature even after the occurrence of an early infection, fish can resist the progression of sub-clinical or latent form of infection toward the expression of disease course signs and lesions. On the other hand, bacterial recovery was carried out from all fish groups challenged at $32 \pm 1^{\circ} \mathrm{C}$ accompanied by the development and progression of gradient of clinical signs and lesions of infections suggesting the critical stressful role played by temperature upon the natural immunity of fish rendering fish immunocompromised and more susceptible to be infected with a wider range of virulent and serum resistant $P$. fluorescens strains. These results support those of Ahne, (1982) who found that additional environmental stress is required for the exaggeration of latent $P$. fluorescens infection in Tench fry. The possibility of increasing disease resistance in ectothermic vertebrates by immunological means has aroused considerable interest. However the situation may be more complex in fish because of inhibition in expression of the immune mechanism at high temperatures (Roberts, 2001). Thus, it could be concluded that high water temperature near or over the maximum temperature tolerant levels has a stressful effect upon the natural immune status of fish rendering fish more susceptible to pseudomonas infections. However, the virulence status of the pathogen itself participate in the establishment of infection as well as magnitude of the exaggerated signs and lesions during disease course.

\section{References}

Abdel-Aziz, E. S. (1988): Some studies on bacterial agents causing tail and fin rot among freshwater fishes in Egypt. M.V.Sc., Thesis, Dept. Inf. Dis., Fac. Vet. Med. Cairo Univ., Egypt.
Ahne, W. ; Poppu, W. and Hoffmann, R. (1982): Pseudomonas fluorescens as a pathogen for Tench (Tinica Tinca). Bull. Eur. Assoc. Fish Path., 2: 56-57.

Allan, B. J. and Stevenson, R. M. W. (1981): Extracellular virulence factors of Aeromonas hydrophila in fish infections. Can. J. Microbiol., 27: $1114-1122$.

Austin, B. and Austin, D. A. (1989): Methods for the microbiological examination of fish and shellfish. Ellis Horwood Limited, England.

Austin, B. and Austin, D. A. (1999): Bacterial Fish Pathogens : Diseases of Farmed and Wild Fish $\left(3^{\text {rd }}\right.$ Rev. ed.), Springer-Praxis Publishing Ltd, Chichester, UK .

Balows, A.; Truper, H. G.; Dworkin, M.; Harder, W. and Schleifer, K. H. (1992): The Prokaryotes , A Handbook on the Biology of Bacteria: Ecophysiology, Isolation, Identification, Applications, $2^{\text {nd }}$ ed. , volume II , Springer - Verlag, NewYork, USA.

Janada, J. M.; Brenden, R. and Bottone, E. J. (1984): Differential Susceptibility to human serum by Aeromonas sp. Cur. Microbiol., 11: 325-328.

Kou, G. H. (1973): Studies on the fish pathogen Aeromonas liquefacient II : The connections between pathogenic properties and the activities of toxic substances. J. Fish. Soc. Taiwan, 2 (1): 42-46.

Krieg, N. R. and Holt, J. G. (1984): Bergey's Manual of Systematic Bacteriology, volume 1, Williams and Wilkins, Baltimore, MD, USA.

Lennette, E. H.; Balows, A.; Hausler, W. J. Jr. and Shadomy, H. J. (1985): Manual of Clinical Microbiology $4^{\text {th }}$ ed. American Society for Microbiology, Washington, D.C.

Mittal, K. R.; Lalonde, G.; Leblanc, D.; Oliver, G. and Lallier, R. (1980): Aeromonas hydrophila in rainbow trout: relation between virulence and surface characteristics. Can. J. Microbiol., 26: 1501-1503.

Noga, E. J. (2000): Fish Disease: Diagnosis and Treatment. $1^{\text {st }}$ ed. , Iowa State Univ. Press/Ames , USA .

Oliver, G.; Evelyn, T. P. and Lallier, R. (1985): Immunogenicity of vaccines from a virulent and an avirulent strain of Aeromonas salmonicida. J. Fish Dis., 8: 43-55

Peterinec, Z.; Naglic, T.; Matasin, Z. and Fijan, N. (1985): Pseudomonas fluorescens septicaemia in bighead carp (Aristichthys nobilis Rich.), following handling. Veterinarski Arch., 55 (6): 277 - 284.

Post, G. (1987): Textbook of fish health. TF.H. Publications, Inc. for revised and expanded edition.

Roberts R. J. (2001): Fish Pathology, $3^{\text {rd }}$ ed., W. B. SAUNDERS, An imprint of Harcourt Publishers Limited, London

Sakai, D. K. (1981): Heat inactivation of complements and immune hemolysis reactions in rainbow trout, masu salmon, coho salmon, goldfish and tilapia. Bull. Jap. Soc. Sci. Fish., 47: 565-571.

Yancey, R. J.; Breeding, S. A. L. and Lankford, C. E. (1979): Enterochelin (Enterobactin): Virulence factor for Salmonella typhimurium. Inf. Imm., 24(1): 174-180. 
تأثير درجة حرارة المياه العالية على المقاومة الطبيعية في أسماك البلطي النيلى المستزرعة

تم استذام نثاط المقاومة الطبيعية لسيرم أسماك البلطي كمؤشر للمناعة الطبيعية فيها ـوقد تم اختبار هذا النشاط في الأسماك التي

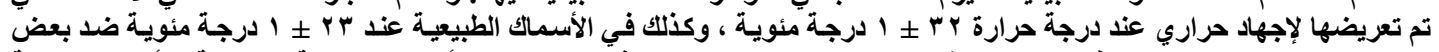

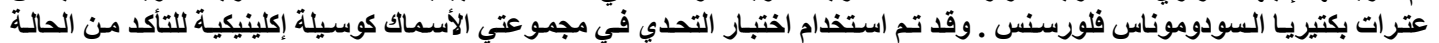

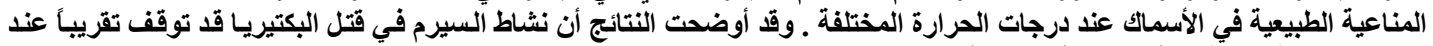

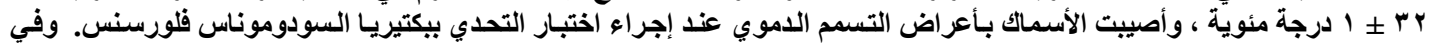

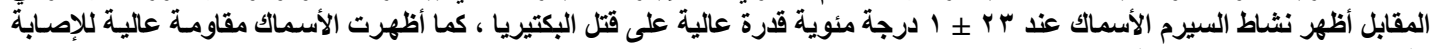
بالمرض غذاب إجراء اختبار التحاي. 
BS. VET. MED. J. VOL. 17, No.1 